\title{
Effect of Blended Fertilizer and Levels of Phosphorus on Yield and Juice Quality of Sugarcane at Fincha Sugar Estate, Ethiopia
}

\author{
Negesse Birhanie ${ }^{1}$, Hirpa Legesse ${ }^{2}$, Zerihun Jalata ${ }^{3, *}$ \\ ${ }^{1}$ Ethiopian Sugar Corporation, Fincha Sugar Estate, Fincha, Ethiopia \\ ${ }^{2}$ Ethiopian Institute of Agricultural Research, Ambo Agricultural Research Center, Ambo, Ethiopia \\ ${ }^{3}$ Department of Plant Sciences, Faculty of Agricultural, Wollega University, Shambu, Ethiopia
}

Email address:

negessebirhanie@gmail.com (N. Birhanie),hirpaleg@gmail.com (H. Legesse),jaluu_z@yahoo.com (Z. Jalata)

${ }^{*}$ Corresponding author

\section{To cite this article:}

Negesse Birhanie, Hirpa Legesse, Zerihun Jalata. Effect of Blended Fertilizer and Levels of Phosphorus on Yield and Juice Quality of Sugarcane at Fincha Sugar Estate, Ethiopia. International Journal of Photochemistry and Photobiology. Vol. 4, No. 2, 2020 , pp. $21-29$. doi: 10.11648/j.ijpp.20200402.11

Received: September 6, 2020; Accepted: September 18, 2020; Published: December 16, 2020

\begin{abstract}
High yield production and juice quality is essential in commercial sugarcane (Saccharum officinarum L.) production. And this is possible is partly influenced by fertilizers. However, especially the effect of phosphorus and blended fertilizers was not known at study area. Field experiment was conducted at Fincha Sugar Estate, Ethiopia in 2018-2019 aiming to determine the effect of blended fertilizers and levels of phosphorus on yield and juice quality of sugarcane. The treatments were arranged in factorial combinations of three blended fertilizers (NPS, NPSB, and NPSBZn) and five phosphorus levels $(0$, 57, 76, 114, and $152 \mathrm{~kg} \mathrm{ha}^{-1}$ ) and the experiment was laid out in randomized complete block (RCB) design with three replications. Data on sugarcane yield and juice quality parameters (Brix\%, pol\%, purity) and sugar yield were collected and analyzed. The result revealed that the main effect and interaction effects of blended fertilizers at different levels of phosphorus were highly significantly $(\mathrm{p}<0.001)$ for all parameters studied except for cane yield and Brix\%. Accordingly, maximum cane yield was recorded in blended fertilizer NPSBZn at levels of phosphorus 152 and $114 \mathrm{~kg} \mathrm{ha}^{-1}$ producing 242.5 and $233 \mathrm{t} \mathrm{ha}^{-1}$, respectively. Thus, cane yield ranged from 106.04 to $242.5 \mathrm{t} \mathrm{ha}^{-1}$ depending on blended fertilizers and levels of phosphorus. The juice quality Brix $\%$, pol\%, purity and sugar yields of NPSBZn at a level of $114 \mathrm{~kg} \mathrm{ha}^{-1}$ phosphorus was superior. Therefore, the finding show the application of blended fertilizer NPSBZn with a level of $114 \mathrm{~kg} \mathrm{ha}^{-1}$ phosphorus was resulted in high cane yield and juice quality of sugarcane.
\end{abstract}

Keywords: Sugarcane, Cane Yield, Juice Quality, Sugar Yield

\section{Introduction}

Sugarcane (Saccharum officinurum L.) is originated from complex hybridization of Saccharum officinarum, Saccharum Spontaneum, Saccharum Barberi, Saccharum Sinense, and related species [17]. Hence, it is a highly polyploidy, heterozygous, and genetically complex crop belongs to family Gramineae (Poaceae). Saccharum officinarum or the noble cane accumulated very high levels of sucrose in the stem. It was usually vegetatively propagated from auxiliary buds on the stem (or stalk) cuttings. The first, "plant" crop was generally harvested from 14 to 16 months after planting; thereafter, "ratoon" crops may be harvested at shorter to equal periods [18]. Sugarcane is an economically important agricultural crop in many tropical and subtropical countries for the production of sugar and biofuels [31]. It was the most efficient photosynthesizer $\mathrm{C} 4$ plant in the plant kingdom. Sugarcane was unique in the sense that the storage of sucrose in the parenchymatous tissue of internodes has taken at higher concentrations. About $70 \%$ of the world sugar was produced from sugarcane and the rest was from sugar beet [14]. The mature stalks of sugarcane have contained juice with sucrose content as low as $8-9 \%$ and as high as $18-19 \%$ [36]. 
Sugarcane production area and productivity differ widely from country to country. Brazil has the highest area $(9.08$ million ha), Australia has the highest productivity (85.1 tons/ha), from 17 top sugarcane producing countries [8]. And it has been indicated that Ethiopia has 700,000 ha of land suitable for sugarcane cultivation which shows the capacity to produce over one billion liters of bio-ethanol [13]. (Girma, 2012). The current total area developed for the production of sugarcane in Ethiopia was only about $33.37 \%$ of the total identified suitable areas [7] (ESISC, 2008). In Ethiopia, currently, there were eight large-scale sugar factories among including Fincha Sugar Estate. The present level of national production from the eight-sugar estates was about 305,956.7 tons of white sugar per annum [33]. This shows high sugarcane production potential of the environment but not efficiently utilized and the annual demand was not yet satisfied. Expanding the area of production was not the only means to meet the national demand for sugar as well as earn foreign currency.

There are many biotic and abiotic factors limiting sugarcane production. However, among abiotic factors, the application level and types of fertilizer was a key factor in sugar production agro-industry [33]. Significantly higher cane and sucrose yield was achieved by the application of the correct fertilizer rates in sugarcane crop production. Nitrogen $(\mathrm{N})$ and phosphorus $(\mathrm{P})$ are the major nutrients required for higher and sustained sugarcane growth, yield, and quality [24]. Application of P, especially on P deficient soils were promoted root growth, stimulated tillering, and influences favorable better growth and thereby better yield and juice quality [3]. The wide variation in soil fertility was a major limitation to obtain higher yield goals which could be improved by balancing N, P, S and micronutrients [31].

Therefore, lack of blended fertilizer type and optimum rate of phosphorus is the major problem in limiting sugarcane yield and juice quality at Fincha Sugar Estate farm. However, the phosphorus rate and blended fertilizer at Finchaa sugar estate area has not been studied so that this research was meant to fill this gap to improve sugarcane yield and quality. Thus, this study was initiated with the aim of investigating the optimum level of Phosphorus and blended fertilizer on growth, yield, and juice quality of sugarcane.

\section{Materials and Methods}

\subsection{Description of Experimental Site}

The experiment was conducted at Finchaa Sugar Factory in the Nile basin, Oromia Regional State in Horro Guduru Wollega Administrative Zone at a distance of around $350 \mathrm{~km}$ Northwest of Addis Ababa. It is located at 9047 '00.35" N latitude and 370 26'13.39" E, longitude and surrounded by steep escarpment along its southern, eastern and western sides, which rises approximately $1446 \mathrm{~m}$ above sea level by (using GPS instrument). The Factory has a semi-arid climate with an average maximum and minimum monthly temperatures of $30.6^{\circ} \mathrm{C}$ and $14.5^{\circ} \mathrm{C}$, respectively. The valley has uni-modal rainfall distribution pattern with alternate wet and dry seasons with the major rain falling between June to September which has an average annual rainfall of $1309 \mathrm{~mm}$ [1]. The valley is positioned between 1350 to $1650 \mathrm{~m}$ above sea level and gently undulating with general slope of 1 to $8 \%$. The soil type at the experimental site is Luvisol which occupies $73 \%$ of the valley's area[38]. Finchaa Sugar Estate is one of the sugar estates in Ethiopia which covers an area of 19,590.74 ha land with sugarcane crops[33].

\subsection{Experimental Material}

Sugarcane cultivar N-14 was used for the experiment based on its desirable agronomic and industrial characteristics and with its high percentage area (47.75\%) coverage from the total area of 19,590.74 ha established in the Finchaa sugar estate. The variety N-14 which was originated in Natal South Africa and introduced from India. It has high stalk mass, tall stalk height, intermediate smut resistance, rapid stalk elongation, rapid canopy formation, profuse flowering, high resistance to lodging, medium stalk population, high cane yield and a higher percent of sucrose as compared to the other varieties growing at the estate (https:// www.sasa.org.za). It is a widely adaptable variety in the sugar estate. The cane variety obtained from seed cane fields of the estate. Healthy three eyes budded setts with an average of 25-30 cm length and uniform diameter was prepared from the middle portion of the seed cane stalk.

Blended Fertilizers: Various types of blended fertilizer as a source of phosphorus like NPS (Nitrogen, phosphorus, and sulphur), NPSB (Nitrogen, phosphorus, sulphur, and Boron), NPSBZn (Nitrogen, phosphorus, sulphur, Boron, and Zinc) with a rate of $(0,57,76,114 \& 152) \mathrm{kg} \mathrm{P}_{2} \mathrm{O}_{5}$.

Treatments and Experimental Design: The treatment consisted of two factors namely different blended fertilizers (NPS, NPSB, and NPSBZn) and phosphorus levels $(0,57$, 76,114 , and $152 \mathrm{~kg} / \mathrm{ha}$ ). The experiment was laid out as a randomized complete block design (RCBD) in a $3 \times 5$ factorial arrangement (Table 1) with three replications. Each experimental plot had four furrows of $5 \mathrm{~m}$ length and $1.45 \mathrm{~m}$ width. The middle two furrows used to collect data and the remaining two furrows used as border rows. The total net area of each plot has 4 rows $(5.8 \mathrm{~m})$ x $5 \mathrm{~m}\left(29 \mathrm{~m}^{2}\right)$. The space between plots and blocks was $1 \mathrm{~m}$ and $2.9 \mathrm{~m}$, respectively. Border space of 3-meter width had left to facilitate observation and serve as the demarcation between the experimental site and commercial field. The treatment combination also based on currently used a rate of $114 \mathrm{~kg}$ of $\mathrm{P}_{2} \mathrm{O}_{5}$ per hectare NPS in the estate and treatments were assigned to each plot randomly.

Table 1. Treatment combinations of the experiment.

\begin{tabular}{ll}
\hline Treatments & Treatments combination \\
\hline 1 & NPS 0 kg $\mathrm{P}_{2} \mathrm{O}_{5}(\mathrm{Control})$ \\
2 & NPS with $57 \mathrm{~kg} \mathrm{P}_{2} \mathrm{O}_{5}$ \\
3 & NPS with $76 \mathrm{~kg} \mathrm{P}_{2} \mathrm{O}_{5}$ \\
4 & NPS with $114 \mathrm{~kg} \mathrm{P}_{2} \mathrm{O}_{5}$ \\
5 & NPS with $152 \mathrm{~kg} \mathrm{P}_{2} \mathrm{O}_{5}$ \\
\hline
\end{tabular}




\begin{tabular}{ll}
\hline Treatments & Treatments combination \\
\hline 6 & NPSB with $0 \mathrm{~kg} \mathrm{P}_{2} \mathrm{O}_{5}$ (Control) \\
7 & NPSB with $57 \mathrm{~kg} \mathrm{P}_{2} \mathrm{O}_{5}$ \\
8 & NPSB with $76 \mathrm{~kg} \mathrm{P}_{2} \mathrm{O}_{5}$ \\
9 & NPSB with $114 \mathrm{~kg} \mathrm{P}_{2} \mathrm{O}_{5}$ \\
10 & NPSBZn with $152 \mathrm{~kg} \mathrm{P}_{2} \mathrm{O}_{5}$ \\
11 & NPSBZn with $0 \mathrm{~kg} \mathrm{P}_{2} \mathrm{O}_{5}$ (Control) \\
12 & NPSBZn with $57 \mathrm{~kg} \mathrm{P}_{2} \mathrm{O}_{5}$ \\
13 & NPSBZn with $76 \mathrm{~kg} \mathrm{P}_{2} \mathrm{O}_{5}$ \\
14 & NPSBZn with $114 \mathrm{~kg} \mathrm{P}_{2} \mathrm{O}_{5}$ \\
15 & NPSBZn with $152 \mathrm{~kg} \mathrm{P}_{2} \mathrm{O}_{5}$ \\
\hline
\end{tabular}

The percent ( $\%)$ of $\mathrm{P}_{2} \mathrm{O}_{5}$ in NPS, NPSB, and NPSBZn was $38,37.4$, and 35.7 , respectively.

\subsection{Soil Analysis}

An initial soil sample at a depth of $0-30 \mathrm{~cm}$ was taken from five randomly selected spots diagonally across the experimental field using auger before planting. Similarly, surface soil $(0-30 \mathrm{~cm}$ depth) samples were collected from every replication of each treatment and bulked to yield a total of 15 composite surface soil samples which is one composite soil sample per treatment after harvesting from the experimental plots. Then the collected soil samples were airdried, grounded, sieved, and analyzed in the soil laboratory of FSRC for selected physicochemical properties mainly organic matter, total $\mathrm{N}$, soil $\mathrm{pH}$, available phosphorus, cation exchangeable capacity (CEC) and textural analysis using standard laboratory procedures.

Organic matter content was determined by the oxidation of organic carbon with acid potassium di-chromate $\left(\mathrm{K}_{2} \mathrm{Cr}_{2} \mathrm{O}_{7}\right)$ medium using the Walkley and Black method as described by Dewis and Freitas [6]. Total nitrogen was analyzed by the Micro-Kjeldahl method [15]. The $\mathrm{pH}$ of the soil was determined in 1:2.5 (weight/ volume) soil to water dilution ratio using a glass electrode attached to digital $\mathrm{pH}$ meter [21]. Cation exchange capacity was measured after saturating the soil with $1 \mathrm{~N}$ ammonium acetate (NH4OAC) and displacing it with $1 \mathrm{~N} \mathrm{NaOAC} \mathrm{[5]} \mathrm{Available} \mathrm{phosphorus} \mathrm{was} \mathrm{determined}$ using the Olsen method [23]. The analysis result on soil properties was summarized and presented in Table 2 and Table 3 .

\subsection{Crop Management Procedures}

Land preparation: The land was conventionally prepared to a fine seedbed with a tractor and the fields were plowed four times and the individual plot was prepared manually.

Seed Cane Preparation: Ten months old, healthy, and three budded of N-14 variety seed cane setts were prepared from the seed cane field of the estate. The setts are prepared uniformly before planting. To protect the setts from various diseases cane knife was immersed in the solution (Ethanol $(50 \%)$ with a rate of one liter of ethanol in one liter of water) for five minutes after each cutting of stool and chopping of one stalk. To protect the chopped setts from soil-borne diseases and pests after planting, the chopped seed material completely immersed in a fungicide called Bumper (propiconazole) $25 \mathrm{EC}$ with a rate of $1 \mathrm{ml}$ per 1liter of water for five minutes using a steel wire basket after treatment [10].

Setts planting: The treated setts were planted in the furrow with $5 \mathrm{~cm}$ overlapping of setts arrangement on the preirrigated experimental field and applied with different sources (NPS, NPSB\& NPSBZn) of phosphorus fertilizer with different rates of $(0,57,76,114$ and $152 \mathrm{~kg} / \mathrm{ha}) \mathrm{P}_{2} \mathrm{O}_{5}$, then again sprayed with a solution of two liters of dursban mixed with 200 liters of water as a per hectare rate basis at the time of planting to protect termite attack and covered with $5 \mathrm{~cm}$ layer of soil. The number of setts planted on $5 \mathrm{~m}$ length of furrow determined on the field at the time of planting based on an average length of setts. Urea fertilizer applied at the age of two months after planting consider with the amount that previously applied at the time of planting.

\subsection{Data Collected}

Cane Yield: Weight of cane /plot obtained using a crane, balance plus weight of sample stalks/plot collected for analysis and stalk parameter recording. This data was calculated by the weight of cane stalk multiplied by total stalk number present on a plot basis (14 months crop age).

Brix: The total soluble solids in the cane juice and it was expressed in Brix degree. This data was recorded by taking 10 cane stalks per plot and crushed the stalks with jefeco grinder. After that disntegrate1000gm of bagasse with $5000 \mathrm{ml}$ of water for 20 minutes and analysis it continuously.

Finally, the Brix \% was measured using hydrometer by making necessary corrections with reference to temperature to obtain true Brix $\%$. This measurement gives the concentration of all soluble compounds in juice, and not only sucrose. It was recorded in 14 months after planting (14-month crop age).

Pol cane /Sucrose: Pol is the actual cane sugar present in the juice. This data was recorded by taking 10 cane stalks per plot and crushed the stalks with jefeco grinder. After that disntegrate $1000 \mathrm{gm}$ of bagasse with $5000 \mathrm{ml}$ of water for 20 minutes and analysis it continuously. Finally, measure the pol\% using Polarimeter by making necessary corrections regarding temperature to obtain true pol\%. This measurement gives the concentration of only sucrose.

Cane purity: It is a solution containing sucrose is the proportion by weight of sucrose to all dissolved solids, expressed as a percentage. It was recorded in 14 months after planting (14-month crop age):

$$
\% \text { Purity }=\frac{\text { Pol x } 100}{\text { Brix }}
$$

Sugar yield: commercial sugar yield (Qt/ha) was calculated as the product of cane yield per hectare and recoverable sucrose percent accordingly. The average recoverable sucrose percent in Fincha is $11.55 \%$. Then sugar yield per hectare was calculated as follows. Sy $(\mathrm{t} / \mathrm{ha})=\mathrm{Cy}(\mathrm{t} /$ ha) x Rs (\%), Where: $\mathrm{Sy}=$ Sugar yield, Rs=Recoverable cane sucrose, $\mathrm{Cy}=\mathrm{Cane}$ yield per hectare

\subsection{Data Analysis}

Data were subjected to analysis of variance (ANOVA) and 
analyzed by using the SAS software version 9.2 with the Proc GLM procedure [29]. Differences between means were separated using the LSD procedure at $5 \%$ and $1 \%$ level of significance.

\section{Results and Discussion}

\subsection{Soil Physico-Chemical Analysis of the Experimental Site}

Soil analysis before planting: The laboratory analysis result conducted at Fincha Sugar Factory Research Center soil laboratory on soil samples before planting and after crop harvesting are given in Table 2 and Table 3 , respectively. The analysis indicated that the soil had medium levels of total nitrogen, available phosphorus, CEC, and low organic matter. The $\mathrm{pH}$ of the soil is 6.67 showing nearly neutral nature of the soil. FAO [8] reported that the preferable $\mathrm{pH}$ ranges for most crops and productive soils are 4 to 8 . Thus, the $\mathrm{pH}$ of the experimental soil is within the range for productive soils. The analytical results indicated that the textural class of the experimental site was mainly of clay soil with a proportion of $49 \%$ Clay, $41 \%$ Sand, and $10 \%$ silt (Table 2 ).

Table 2. Selected physicochemical properties of soil of the study area before planting.

\begin{tabular}{llllllll}
\hline \multicolumn{2}{l}{ Physical properties } & \multicolumn{2}{l}{ Chemical properties } \\
\hline \multicolumn{2}{l}{ Particle size distribution (\%) } & Textural Class & pH (1:2.5 H2O) & M (\%) & Total N (\%) & Avail P (ppm) & CEC (cmol/kg) \\
\hline Sand & Silt & Clay & & & & & \\
\hline 21 & 30 & 49 & Clay & 6.67 & 1.95 & 0.19 & 9.91 \\
\hline
\end{tabular}

Table 3. Effects of blended fertilizers and phosphorus levels on some soil chemical properties after harvesting.

\begin{tabular}{lllll}
\hline Treatments & pH (1:2.5 H2O) & OM (\%) & Total N (\%) & Ava P (ppm) \\
\hline BF & & & & CEC (cmol/kg) \\
\hline NPS & 7.09 & 0.97 & 0.091 & 6.76 \\
NPSB & 7.09 & 0.96 & 0.095 & 6.77 \\
NPSBZn & 7.08 & 0.96 & 0.091 & 6.78 \\
Mean & 7.09 & 0.96 & 0.092 & 6.77 \\
LSD (0.05) & NS & NS & NS & NS \\
\hline
\end{tabular}

$P$ - Levels $\mathrm{kg} \mathrm{ha} \mathrm{H}^{-1}$

\begin{tabular}{llllll}
\hline $\mathbf{0}$ & $\mathbf{7 . 0 9}$ & $\mathbf{0 . 9 4}$ & $\mathbf{0 . 0 9 0}$ & $\mathbf{6 . 7 5}$ & $\mathbf{2 9 . 6 0}$ \\
\hline 57 & 7.09 & 0.95 & 0.088 & 29.62 & 29.77 \\
76 & 7.09 & 0.97 & 0.094 & 6.65 \\
114 & 7.08 & 0.98 & 0.090 & 29.60 \\
152 & 7.11 & 0.95 & 0.091 & 6.80 \\
Mean & 7.09 & 0.96 & 0.092 & 6.77 \\
LSD $(0.05)$ & NS & NS & NS & NS \\
\hline
\end{tabular}

$\mathrm{NS}=$ is not significantly different at $5 \%$ level of probability. $\mathrm{LSD}=$ Least significant difference and, $\mathrm{P}=$ phosphorus, $\mathrm{BF}=\mathrm{blended}$ fertilizer, $\mathrm{P}=$ prosperous levels.

Soil analysis after harvesting: Soil $\mathrm{pH}$, available $\mathrm{P}$, total $\mathrm{N}$, organic matter and CEC were measured to assess the postharvest status of the soil. The blended fertilizers and levels of phosphorus exhibited non-significant effects on the above soil attributes (Table 3). Analysis of the soil samples after harvesting showed a reduction in total nitrogen, available $\mathrm{P}$, and organic matter as compared to the contents before planting (Table 2, Table 3). The reason for the reduction of total soil nitrogen (from $0.092 \%$ ) may be due to the removal of soil $\mathrm{N}$ through the vegetative growth of the crops. Other losses could be via denitrification, leaching, volatilization, and/or their combination [36]. Similarly, the available P and organic matter content of the experimental soil also declined from $9.91 \mathrm{ppm}$ and $1.95 \%$ at planting to $6.77 \mathrm{ppm}$ and $0.96 \%$ post-harvesting due to their utilization by the growing crop, respectively (Table 3 ).

Cation exchange capacity (CEC) is also an important parameter of soil because it indicates the type of clay mineral present in the soil and its capacity to retain nutrients against leaching. According to Sahlemedihn [27], CEC by sodium acetate at $\mathrm{pH} 8.2$ or ammonium acetate at $\mathrm{pH} 7.0$ methods with values between 25 and $40 \mathrm{cmol} \mathrm{kg}^{-1}$ were high to medium and satisfactory for agriculture with the use of fertilizer. Accordingly, the CEC (ammonium acetate at $\mathrm{pH}$ 7.0) of the experimental soil is $26.45 \mathrm{cmol} \mathrm{kg}^{-1}$ (at planting) and increased to $29.63 \mathrm{cmol} \mathrm{kg}^{-1}$ (after harvesting) (Table 3).

\subsection{Effect of Blended Fertilizers and Levels of Phosphorus on Cane Yield}

Cane Yield: Analysis of variance showed a significant difference $(\mathrm{P}<0.01)$ for the main effects of blended fertilizer treatments and phosphorus rates for cane yield per hectare. But blended fertilizers and phosphorus rates interaction had a non-significant effect on cane yield per hectare (Table 4). NPSBZn which is highly influenced by blended fertilizer had the maximum cane yield (220.77 ton $\left.\mathrm{ha}^{-1}\right)$ while mean cane yield per hectare for blended fertilizers showed that NPSB and NPS had the minimum cane yield (184.27 and 173.09 ton $\mathrm{ha}^{-1}$ ), respectively (Table 5). This may be because of the blended fertilizer NPSBZn has a maximum number of tillers, millable canes, plant height, and thickness of cane stalks than the rest of blended fertilizers. So, cane yield is a function of cane weight and the number of millable canes. This finding 
conforms to Shrivastava [30] who reported that cane yield is a result of approximately $70 \%$ of millable canes, $27 \%$ of cane length, and $3 \%$ of cane girth. Toomsan and Limpinuntana [37] indicated that higher cane yield could be attributed to the higher number of tillers and millable cane. Jiang [16] also reported that the sugarcane yield per unit of land is composed of the millable canes and the cane weight. $\mathrm{Zn}$ application significantly affected the quantitative parameters of sugarcane including the yield of cane stalks [30].

Table 4. Analysis of variance showing mean square values for yield and juice quality parameters of sugarcane as affected by blended fertilizers, level of phosphorus, and interaction of both factors at Fincha Sugar Estate in 2018/19 cropping season.

\begin{tabular}{|c|c|c|c|c|c|c|}
\hline \multirow{2}{*}{ Source of Variation } & \multirow{2}{*}{ DF } & \multicolumn{5}{|c|}{ Mean square } \\
\hline & & cane yield & brix \% & pol\% & Purity\% & Sugar yield \\
\hline Rep & 2 & 1762.67 & 0.27 & 0.17 & 6.66 & 41.99 \\
\hline $\mathrm{BF}$ & 2 & $9325.10^{* *}$ & $3.77^{* *}$ & $.69^{* * *}$ & $47.01^{* *}$ & $364.85^{* *}$ \\
\hline P- Levels & 4 & $27195.23^{* *}$ & $4.74^{* *}$ & $9.53^{* *}$ & $44.30^{* *}$ & $501.88^{* *}$ \\
\hline $\mathrm{BF} * \mathrm{P}-$ Levels & 8 & $554.41^{\mathrm{ns}}$ & $0.94^{\mathrm{ns}}$ & $1.57^{*}$ & $48.42^{* * *}$ & $49.15^{* *}$ \\
\hline Error & 28 & 533.49 & 0.46 & 0.49 & 7.68 & 7.69 \\
\hline $\mathrm{CV}$ & & 11.98 & 3.93 & 4.49 & 3.07 & 12.66 \\
\hline
\end{tabular}

$* * * * *$ and $*$ significance at $0.001,0.01$ and at 0.05 level of probability, respectively, ns $=$ non significant, $\mathrm{CV}=$ coefficient of variation; $\mathrm{P}=\mathrm{phosphorus,}$ $\mathrm{BF}=$ blended fertilizer.

Table 5. The main effect of blended fertilizers and levels of phosphorus on cane yield and Brix juice of sugarcane at Fincha Sugar Estate in $2018 / 19$ cropping season.

\begin{tabular}{lll}
\hline Treatment & Cane yield (ton ha $\left.{ }^{-1}\right)$ & Brix (\%) \\
\hline Blended Fertilizers (BF) & $17.45^{\mathrm{a}}$ \\
\hline NPS & $184.27^{\mathrm{b}}$ & $16.81^{\mathrm{b}}$ \\
NPSB & $173.09^{\mathrm{b}}$ & $17.79^{\mathrm{a}}$ \\
NPSBZn & $220.77^{\mathrm{a}}$ & 0.17 \\
SE \pm & 5.96 & 0.51 \\
LSD $(0.05)$ & 17.27 & $16.22^{\mathrm{c}}$ \\
P-Levels $\left(\mathrm{Kg} \mathrm{ha}^{-1}\right)$ & & $17.15^{\mathrm{b}}$ \\
0 & $106.04^{\mathrm{d}}$ & $17.47^{\mathrm{ab}}$ \\
57 & $175.75^{\mathrm{c}}$ & $18.10^{\mathrm{a}}$ \\
76 & $206.26^{\mathrm{b}}$ & $17.81^{\mathrm{ab}}$ \\
114 & $233.00^{\mathrm{a}}$ & 0.22 \\
152 & $242.51^{\mathrm{a}}$ & 17.35 \\
SE \pm & 7.69 & 0.19 \\
Mean & 192.71 & 3.93 \\
LSD $(0.05)$ & 22.30 & 1.98 \\
\hline
\end{tabular}

Means followed by the same letters are not significantly different at $5 \%$ level of significance according to the LSD test. CV=coefficient of variation, $\mathrm{LSD}=$ Least significant difference, and $\mathrm{SE}=\mathrm{Standard}$ of error, $\mathrm{P}=$ phosphorus.

Mean values for phosphorus rates showed that cane yield per hectare increased with each increment of phosphorus rates from the control to the highest rate but the two higher $P$ rates are statistically at par (Table 5). The increased cane yield at the highest level of phosphorus was probably due to the availability of more nutrients, which helped for the occurrence of maximum cane weight and the number of millable canes. This result was in line with Bokhtail and Sakurai [4] who reported that the application of P, especially on $\mathrm{P}$ deficient soils stimulates tillering, and influences favorable better growth and thereby better cane yield. Maximum cane yield (242.51 and 233 ton $\mathrm{ha}^{-1}$ ) was recorded at $\mathrm{P}$ rate of 152 and $114 \mathrm{~kg} \mathrm{ha}^{-1}$, respectively, while minimum cane weight (106.04 ton $\left.\mathrm{ha}^{-1}\right)$ was recorded in the control $(0$ $\mathrm{kg} \mathrm{ha}^{-1}$ ) (Table 5) indicating that $\mathrm{P}$ rates of 152 and $114 \mathrm{~kg}$ $\mathrm{ha}^{-1}$ were not statistically significant to influence cane weight but $\mathrm{P}$ rates of $152 \mathrm{~kg} \mathrm{ha}^{-1}$ were showed better influence than $114 \mathrm{~kg} \mathrm{ha}^{-1}$ of $\mathrm{P}$ rates. This finding was lined with Omollo and Abayo [24] who reported that the levels of P increases significantly increased cane weight, plant height, and cane yield.

\subsection{Effect of Blended Fertilizers and Levels of Phosphorus on Sugarcane Juice Quality}

Brix of Juice (\%): Analysis of variance showed significant differences $(\mathrm{P}<0.01)$ for the main effect of blended fertilizer treatments at various rates of phosphorus for brix of juice (Table 4). But the interaction effect of blended fertilizers and phosphorus rates was non-significant for brix of juice. Mean Brix percentage for blended fertilizers showed that NPS had the minimum Brix of juice (16.81\%) while NPSBZn and NPSB which are highly influenced blended fertilizer had the maximum Brix percentage (17.79\% and $17.45 \%$ ), respectively (Table 5). This is because of micronutrients significantly affected the juice quality directly. This result was in line with Ghaffar et al. [12] report on $\mathrm{Zn}$ and B application in addition to NPS to sugarcane fields significantly affected the sugarcane juice including brix, pol, and purity. Franco et al. [11] also reported that the beneficial effect of $\mathrm{Zn}$ should be highlighted because its application significantly increased the values of 
brix percentage. So, brix (total soluble solids in a juice) is one of the qualitative parameters used for maturity judgment in sugar cane production [28].

Mean brix percentage for phosphorus rates showed that increased with each increment of phosphorus rates from the control to the highest rate up to a maximum point of phosphorus rates $\left(114 \mathrm{~kg} \mathrm{ha}^{-1}\right)$ and above these rates of phosphorus the effect was immediately decreased (Table 5). The increased brix percentage at the highest level of phosphorus was probably due to the availability of more nutrients, which helped for the accumulation of maximum brix in the cane juice. This result was in line with Pannu et al. [26] who reported that $\mathrm{P}$ application with different rates increase and conducive for higher brix percentage and sugar accumulation in cane juice. Malie et al.[20] reported that increasing phosphorus rates especially on $\mathrm{P}$ deficit soils increased the percentage of brix of sugar cane juice. However, as opposed to this result, Pannu et al., [26] and Majeedamo et al. [19] expressed the adverse effect of high phosphorus rate of application on brix of cane juice. The maximum percentage of brix $(18.10 \%)$ followed by $(17.81 \%$ and $17.47 \%$ ) was recorded at $\mathrm{P}$ rate of $114 \mathrm{~kg} \mathrm{ha}^{-1}, 152 \mathrm{~kg} \mathrm{ha}^{-1}$ and $76 \mathrm{~kg} \mathrm{ha}^{-1}$, respectively, while the minimum percentage of brix $(16.22 \%)$ was recorded in the control $\left(0 \mathrm{~kg} \mathrm{ha}^{-1}\right)$. In general, in this study the percentage of brix for blended fertilizers and phosphorus rates ranged between $16.81 \%$ (NPS) and $17.79 \%$ (NPSBZn), 16.22\% $\left(0 \mathrm{~kg} \mathrm{ha}^{-1}\right)$ and 18.10\% (114 $\left.\mathrm{kg} \mathrm{ha}^{-1}\right)$ (Table 5).

Polarization of Juice (\%): Analysis of variance showed significant differences $(\mathrm{P}<0.01)$ among blended fertilizer treatments, phosphorus rates, and their interaction for the pol percentage of juice. The interaction effect between rates of blended fertilizers at various phosphorus rates was found to be significant $(\mathrm{P}<0.05)$ for pol percentage (Table 4$)$. NPSBZn blended fertilizer rate showed maximum pol percentage $(17.70 \%$ and $17.58 \%)$ at the highest rate of phosphorus (114 and $152 \mathrm{~kg} \mathrm{ha}^{-1}$ ) application respectively (Table 6). This may be because zinc proved to highly effective, even when applied without boron in addition to NPS. Similarly, Bokhtiar et al.[4] indicated the highest pol percentage with micronutrient application including zinc. And combined application of boron and zinc proved to be more beneficial as compared to $\mathrm{Zn}$ or B application alone [22]. The rest of the blended fertilizers obtained maximum pol percentage at the $\mathrm{P}$ rate application of $57 \mathrm{~kg} \mathrm{ha}^{-1}(16.55 \%)$ and $114 \mathrm{~kg} \mathrm{ha}^{-1}$ $(15.80 \%)$ for NPSB and NPS, respectively. Blended fertilizers NPSB showed maximum pol percentage at the control treatment compared to the rest of blended fertilizer (Table 6).

Table 6. Interaction effect of blended fertilizers and levels of phosphorus on pol percentage and purity percentage of sugarcane juice at Fincha sugar Estate in 2018/19 cropping season.

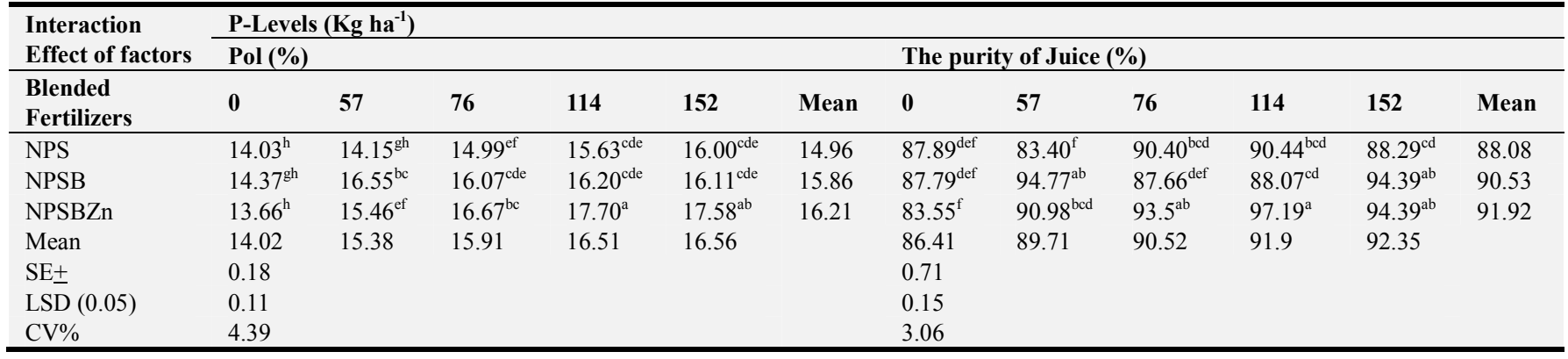

Table 7. Interaction effect of blended fertilizers and levels of phosphorus on sugar yield of sugarcane at Fincha Sugar Estate in $2018 / 19$ cropping season.

\begin{tabular}{|c|c|c|c|c|c|c|}
\hline \multirow{3}{*}{$\begin{array}{l}\text { Interaction Effect of factors } \\
\text { Blended Fertilizers }\end{array}$} & \multicolumn{6}{|c|}{ P-Levels $\left(\mathrm{Kg} \mathrm{ha}^{-1}\right)$} \\
\hline & \multicolumn{6}{|c|}{ Sugar yield (ton ha ha $^{-1}$} \\
\hline & $\mathbf{0}$ & 57 & 76 & 114 & 152 & Mean \\
\hline NPS & $10.74^{\mathrm{f}}$ & $16.35^{\mathrm{de}}$ & $21.20^{\text {bcd }}$ & $22.06^{\mathrm{bc}}$ & $22.92^{\text {bc }}$ & 18.65 \\
\hline NPSB & $9.80^{\mathrm{f}}$ & $17.72^{\mathrm{cd}}$ & $20.79^{\text {bcd }}$ & $25.37^{\mathrm{b}}$ & $23.61^{\mathrm{b}}$ & 19.45 \\
\hline NPSBZn & $12.02^{\mathrm{ef}}$ & $23.03^{\mathrm{b}}$ & $24.66^{\mathrm{b}}$ & $40.77^{\mathrm{a}}$ & $41.37^{\mathrm{a}}$ & 27.57 \\
\hline Mean & 10.85 & 19.03 & 22.21 & 28.06 & 29.3 & \\
\hline $\mathrm{SE} \pm$ & 0.71 & & & & & \\
\hline $\mathrm{CV} \%$ & 14.42 & & & & & \\
\hline
\end{tabular}

Means followed by the same letters are not significantly different at $5 \%$ level of significance according to the LSD test. CV=coefficient of variation, $\mathrm{LSD}=$ Least significant difference, and $\mathrm{SE}=\mathrm{Standard}$ of error, $\mathrm{P}=$ phosphorus.

On the other hand, NPSBZn and NPS Blended fertilizers showed the lowest pol percentage for the control treatment (Table 5). In general, in this study, the percentage of pol ranged between $13.66 \%$ (NPSBZn) and $17.70 \%$ (NPSBZn) (Table 6). However, reports of Pannu et. al. [26] and Majeedamo et al.[19]contradict the present study by reporting the adverse effect of high phosphorus rate of application on the percentage of pol in cane juice.

The purity of juice $(\%)$ : The result showed significant differences $(\mathrm{P}<0.01)$ among blended fertilizer treatments, phosphorus rates, and their interaction effect for purity of sugarcane juice (Table 4). Furthermore, NPSBZn blended fertilizer was showed maximum purity of juice $(97.19 \%)$ at the highest rate of phosphorus $114 \mathrm{~kg} \mathrm{ha}^{-1}$ (Table 6) 
indicating zinc proved to be highly effective, even when applied without boron in addition to NPS. This study conforms to Bokhtiar et al.[4]. Mariano et al. [22] also reported that the combined application of boron and zinc proved to be more beneficial as compared to $\mathrm{Zn}$ or $\mathrm{B}$ application alone. Franco et al. [11] also reported that the beneficial effect of $\mathrm{Zn}$ should be highlighted because its application significantly increased the values of sugar yields. The rest of the blended fertilizers obtained maximum juice purity percentage at the $\mathrm{P}$ rate application of $152 \mathrm{~kg} \mathrm{ha}^{-1}$ (94.39\%) and $57 \mathrm{~kg} \mathrm{ha}^{-1}(94.77 \%)$ for NPS and NPSB, respectively. Blended fertilizers NPS \& NPSB showed maximum juice purity $(87.89 \%$ and $87.79 \%)$ at the control treatment, respectively compared to the rest one blended fertilizer. On the other hand, NPSBZn blended fertilizers were lowest for juice purity $(83.55 \%)$ at the control treatment. In general, in this study, the purity juice ranged between $83.55 \%$ (NPSBZn) and 97.19\% (NPSBZn) (Table 6). However, Pannu et al.[26] and Majeedamo et al. [19] report the adverse effect of high Phosphorus rate of application on the purity of juice. Farias et al.[9]also did not confirm the $\mathrm{Zn}$ benefits in the sugarcane technological quality including purity of juice. This deviation might be due to the different in climatic and soil conditions.

Sugar Yield: The result showed significant differences $(\mathrm{P}<0.01)$ among blended fertilizer treatments, phosphorus rates, and their interaction for sugar yield (Table 4). NPSBZn blended fertilizer was showed maximum sugar yields (41.37 and 36.77) ton $\mathrm{ha}^{-1}$ at the highest rate of phosphorus (152 and $114 \mathrm{~kg} \mathrm{ha}^{-1}$ ) application, respectively (Table 7) showing that zinc proved to be highly effective, even when applied without boron in addition to NPS. And Bokhtiar et al., [4] also obtained the highest sugar yield with micronutrient applications including zinc. Mariano et al.[22] reported that the combined application of boron and zinc proved to be more beneficial as compared to $\mathrm{Zn}$ or $\mathrm{B}$ application alone. The rest of blended fertilizers obtained maximum sugar yield at the $\mathrm{P}$ rate application of 152 and $114 \mathrm{~kg} \mathrm{ha}^{-1}$ for NPS and
NPSB, respectively. Blended fertilizers NPSBZn showed maximum sugar yields at the control treatment compared to the rest of one blended fertilizer (Table 7). Similarly, Franco et al. [11] reported the beneficial effect of $\mathrm{Zn}$ should be highlighted because its application significantly increased the values of sugar yields.

Another report showed maximum cane yield (tons/hectare), millable cane, and cane weight $(\mathrm{kg})$ were obtained at two locations from the treatment and blended fertilizer was reported to have better effect on growth and cane yield of sugarcane than straight fertilizer [2](Afghan et al., 2014). Furthermore, soil application of $\mathrm{Zn}$ enhanced cane yield (111.9 $\mathrm{t} \mathrm{ha}^{-1}$ ) and the foliar application of $\mathrm{B}$ resulted produced highest cane yield attributes specifically cane yield (107.4 t ha-1), brix (21.9\%). And its interaction effects increased distinctively cane yield (119.0 t ha-1) and brix (24.0\%), [21] (Mangrio1 et al., 2020).

On the other hand, NPS and NPSB Blended fertilizers showed the lowest sugar yields at the control treatment. In general, in this study, the yield of sugar ranged between 9.80 ton $\mathrm{ha}^{-1}$ (NPSB) to 41.37 ton $\mathrm{ha}^{-1}$ (NPSBZn) (Table 7). As opposed to this, Pannu et al.[26] and Majeedamo et al.,[19] indicating the adverse effect of high Phosphorus rate of application on cane juice quality and sugar yield. Farias et al. [9] also did not confirm the $\mathrm{Zn}$ benefits in the sugarcane technological quality including sugar yield.

\subsection{Economic Analysis of Blended Fertilizers and Levels of PHOSPHORUS on Sugar Yield}

Economic returns of sugarcane due to fertilizer application were worked out according to prices of fertilizer and sugarcane during 2018/19. It is evident from data in Table 8 that maximum Economics returns (19405.44 USD) was obtained from NPSBZn $114 \mathrm{~kg} \mathrm{ha}^{-1}$ followed by NPSBZn $152 \mathrm{~kg} \mathrm{ha}^{-1}$ and NPSB $114 \mathrm{~kg} \mathrm{ha}^{-1}$ with Economic returns (19347.66 USD and 12031.71 USD, respectively, as compared to control treatment.

Table 8. Economic Analysis of Sugar yields ha ${ }^{-1}$ due to Blended Fertilizers and levels of Phosphorus Application at Fincha Sugar Estate in $2018 / 2019$ cropping season.

\begin{tabular}{|c|c|c|c|c|c|c|}
\hline Blended Fertilizers & $\begin{array}{l}\text { P- levels } \\
\text { (Kg) }\end{array}$ & $\begin{array}{l}\text { Sugar yields } \\
\text { (tons) }\end{array}$ & $\begin{array}{l}\text { Increased sugar } \\
\text { (tons) }\end{array}$ & $\begin{array}{l}\text { Gross income } \\
\text { (USD) }\end{array}$ & $\begin{array}{l}\text { Cost of fertilizers } \\
\text { (USD) }\end{array}$ & $\begin{array}{l}\text { Net income } \\
\text { (USD) }\end{array}$ \\
\hline NPS & 0 & 10.74 & - & 5155.2 & 50.6 & 5104.6 \\
\hline NPS & 57 & 16.35 & 5.61 & 7848.0 & 102.5 & 7745.5 \\
\hline NPS & 76 & 21.20 & 10.46 & 10176 & 119.8 & 10056.2 \\
\hline NPS & 114 & 22.06 & 11.32 & 10588.8 & 154.4 & 10434.4 \\
\hline NPS & 152 & 22.92 & 12.18 & 11001.6 & 189.0 & 10812.6 \\
\hline NPSB & 0 & 9.8 & - & 4704.0 & 50.6 & 4653.4 \\
\hline NPSB & 76 & 20.79 & 10.99 & 9979.2 & 114.1 & 9865.1 \\
\hline NPSB & 114 & 25.37 & 15.57 & 12177.6 & 145.9 & 12031.7 \\
\hline NPSB & 152 & 23.61 & 13.81 & 11332.8 & 177.3 & 11155.6 \\
\hline NPSBZn & 0 & 12.02 & - & 5769.6 & 50.6 & 5719.0 \\
\hline NPSBZn & 57 & 23.03 & 11.01 & 11054.4 & 106.9 & 10947.5 \\
\hline NPSBZn & 76 & 24.66 & 12.64 & 11836.8 & 125.6 & 11711.2 \\
\hline NPSBZn & 114 & 40.77 & 28.75 & 19569.6 & 163.2 & 19406.3 \\
\hline
\end{tabular}

N. B: Prices of NPS: 0.423 USD/kg, NPSB: $0.44 U S D$ NPSBZn: $0.44 U S D / k g$ and Urea: $0.41 \mathrm{USD} / \mathrm{kg}$. Other costs were similarly used on each treatment. 
The statistical analysis showed that the main effect and interaction effects of the main effect of blended fertilizers at different levels of phosphorus were highly significantly $(\mathrm{p}<0.001)$ for all parameters studied except for cane yield and brix $\%$ where interaction effect was not significant. Thus, the maximum cane yield was recorded in the blended fertilizer NPSBZn with 152 and $114 \mathrm{~kg} \mathrm{ha}^{-1}$ levels of phosphorus. The maximum mean values of brix were recorded in NPSBZn and NPS (17.79 \&17.45\%), respectively. The highest mean value of brix $(18.10 \%)$ was obtained from plots treated with $114 \mathrm{~kg} \mathrm{ha}^{-1}$ level of phosphorus. Similarly, the highest polarization $(17.70 \%)$ was obtained from NPSBZn fertilizer at the levels of $114 \mathrm{~kg} \mathrm{ha}^{-1}$ phosphorus while the lowest pol (14.03 and 14.37\%) was recorded from NPSB and NPSBZn at the control of $0 \mathrm{~kg} \mathrm{ha}^{-1}$ phosphorus levels. While the highest cane juice purity $(97.19 \%)$ was obtained from NPSBZn fertilizer at the levels of $114 \mathrm{~kg} \mathrm{ha}^{-1}$ phosphorus. And the highest sugar yields 40.77 tons $\mathrm{ha}^{-1}$ was obtained from NPSBZn fertilizer at the levels of $114 \mathrm{~kg} \mathrm{ha}^{-1}$ phosphorus while the lowest $\left(10.74\right.$ and 9.8 tons ha $^{-1}$ ) was recorded from NPSB and NPS at the control of $0 \mathrm{~kg} \mathrm{ha}^{-1}$ phosphorus levels, respectively. Generally, it can be suggested based on cane yield and juice quality and economical analysis, blended fertilizer NPSBZn and $114 \mathrm{~kg}$ ha-1 was the best-blended fertilizer and correct combination among the rest blended fertilizers and levels of phosphorus.

\section{Statement of Conflict of Interest}

The authors declare that there is no conflict of interest.

\section{Acknowledgments}

We thank Fincha Sugar Factor for their administration support and provision of experimental field.

\section{References}

[1] Ademe, Adnew, 2001. Summary of Metrological Data (19792000), Fincha, Research Station. Fincha, Ethiopia. http://www.innspub.net/wp-content/uploads/2013/10/JBESVol3No11-p31-47.pdf.

[2] Afghan, S, Ghous, G, Ali, K, Hussain, K, Hasnain, Z. and Mushtaq, M.S. 2014. Impact of blended vs straight fertilizer on growth, yield and quality of sugarcane. Sugar cane international, month/month 2004, 22 (X): 10-12.

[3] Bokhtail, S. M and Sakurai, K. 2003. Sugarcane Response to Soil Phosphorus. Better Crops International. 17 (1): 20-25. http://www.ipni.net/publication/bci.nsf/0/2785C36FB3C7C15 F85257BBA0064B64C/\$FILE/Better\%20Crops\%20Internatio nal\%202003-1\%20p20.pdf.

[4] Bokhtiar, S. M., Paul, G. C and Kabir, M. L 2001. Effect of sulfur fertilization on the yield of sugarcane in char land. Bangladesh Journal of Training and Development 14 (1/2):
57-62.

http://www.ipni.net/publication/bci.nsf/0/2785C36FB3C7C15 F85257BBA0064B64C/\$FILE/Better\%20Crops\%20Internatio nal\%202003-1\%20p20.pdf.

[5] Chapman, H. D., 1965. Cation Exchange capacity. Black, CA, Ensminger LE, Clark FE (eds). Method of soil analysis. American Society of Agronomy, pp. 891-901, Madison Wisconsin, USA. https://doi.org/10.2134/agronmonogr9.2.

[6] Dewis, J and Freitas, P. 1970. Physical and chemical methods of soil and analysis FAO Bulletin No. 10. Rome. 175p. https://www.cabdirect.org/cabdirect/abstract/19711901105.

[7] ESISC (Ethiopian Sugar Industry Support Center Share Company. 014. Investment Opportunity in Sugar Cane Plantation In $\quad$ Ethiopia. http://www.ethiopianembassy.org.in/investment/Opportunity \%20in\%20Sugar\%20Cane\%20Plantation\%202014.pdf.

[8] FAO, 2000. Fertilizers and their use: A pocket guide for extension officers. $4^{\text {th }}$ edition International fertilizer industry association FAO, Rome, Italy. http://www.fao.org/tempref/agl/agll/docs/fertuse.pdf.

[9] Farias, C. H. A.; Fernandes, P. D.; Gheyi, H. R and Dantas Neto, J. 2009. Effect of micronutrients on sugarcane quality parameters in Brazil sugarcane estates, v. 13, p. 419-428. HTTP:// dx.doi.org/10.1590/S1415-43662009000400008.

[10] Fincha Sugar Factory, 2016. Operational Standard procedure for sugarcane production in Fincha Sugar Estate. https://www.ethiopiansugar.com/finchaa-sugar-factory/.

[11] Franco, H. C J, Franco, Eduardo Mariano, Andre' C. Vitti, Carlos E. Faroni, Rafael Otto, Paulo C. O. Trivelin, 2011. Sugarcane Response to Boron and Zinc in Southeastern Brazil. Sugar Tech (Jan-Mar 2011) 13 (1): 86-95. DOI 10.1007/s12355-010-0057-x.

[12] Ghaffar, A, Ehsanullah, N Akbar, S. H, Khan, K, Jabran, R. Q, Iqbal, H. A and Ali, M. A. 2012. Effect of trench spacing and micronutrients on growth and yield of sugarcane (Saccharum officinarum L.). Australian Journal of Crop Sciences, 6 (1): 19.

[13] Girma, A. 2012. Prospects and Challenges of Bio Ethanol Production from Molasses in the Ethiopian Sugar Industry, MSc thesis, Indra Gandhi National Open University, India. 80. p.

[14] Godheja. J, Sudhir, K. S, and Modi,. D. R. 2014. The Standardization of Protocol for large-scale production of sugarcane (co-86032) through micro propagation. International Journal of Plant, animal, and environmental Sciences 4 (4). https://www.semanticscholar.org/paper/THESTANDARDIZATION-OF-PROTOCOL-FOR-LARGESCALE-OF-Godheja-

Shekhar/057c5855719607194bcc35b4d935a28182c3b16a.

[15] Jackson, M. L. 1958. Soil Chemical Analysis. Prentice Hall, inc. Englewood, cliff, N. J. 372-374.

[16] Jiang, Y. M, 2004. Modern Sugarcane Cultivation Technology. Sugarcane Industry Research Institute. Guangzhou, China. Soils misconceptions and knowledge gaps: Plant and soil 248, 31-41. https://cdn.intechopen.com/pdfs/59391.pdf. 
[17] Khan, S. A, Rashid, H, Chaudhary, Chaudhry, M. F, Chaudhry Z, Fatima Z, Sadar Uddin Siddiqui, S. U, Zia, M 2009. Effect of Cytokinin on Shoot Multiplication in Three Elite Sugarcane Varieties. Pakistan Journal of Botany, 41: 1651-1658.

file:///C:/Users/HP/Downloads/Effect_of_cytokinins_on_shoo t_multiplication_in_th.pdf.

[18] Khan, I. A., Javed, M. A., Khatri, A., Siddiqui, M. A,. Khan M. K. R, Dahar, NA., Khanzada M. H, and Khan,. R. 2002. Performance of exotic sugarcane clones at NIA, Tando Jam. Asian Journal of. Plant Scence, 1: 238-240. DOI: 10.3923/ajps.2002.238.240.

[19] Majeedamo, H. I., Minhas,. Y. J, Jarwa, A. D., Tunio, S. D and Puno, H. P. 2003. Effect of phosphorus levels and methods of application on sugarcane yield. Pakistan Sugar $\begin{array}{llllll}\text { Journal. } & 18 & \text { (4): } & 17 & - & 19 .\end{array}$ file:///C:/Users/HP/Downloads/Pakistan_Sugar_Journal.pdf.

[20] Malie, S. A.,. Parwar, K. R and Barulkar, D. N, 2015. Yield contributing characters of three varieties of seasonal sugarcane as Influenced by Nitrogen and phosphorus, Indian Sugar 32: 95-104.

http://repository.sustech.edu/bitstream/handle/123456789/216 76/Research.pdf?sequence $=3$ \&isAllowed $=y$.

[21] Mangrio, N, Kandhro, M. N, Soomro, A. A, Mari, N. and Shah, Z. H. 2020. Growth, yield and sucrose percent response of sugarcane t zinc and boron application. Sarhad Journal of $\begin{array}{llll}\text { Agriculture, } & 36 & \text { (2): }\end{array}$ http://dx.doi.org/10.17582/journal.sja/2020/36.2.459.469.

[22] Mariano, F. H., Vitti, E, Faroni, A, Otto, C and Paulo, R. T 2011. Sugarcane Response to Boron and Zinc in Southeastern Brazil. Sugar Tech, 13 (1): 86-95.10.1007/s12355-010-0057$\mathrm{x}$.

[23] Olsen, S. R., Cole, C. W., Watanabe, F. S, and Dean, L. A. 1954. Estimation of available phosphorous in soils by extraction with sodium bicarbonate circular 939, US. Department of agriculture. https://www.worldcat.org/title/estimation-of-availablephosphorus-in-soils-by-extraction-with-sodiumbicarbonate/oclc/17316676.

[24] Omollo, J. O, and Abayo. G. O. 2011. Effect of phosphorus sources and rates on sugarcane yield and quality in Kibos, Nyando Zone. Springer Science+Business Media B. V., DOI. 10.1007/978-90-481-2543-

2 55https://landmatrix.org/media/uploads/sinfonaplresourceb wmetal elementspringer-395fbdea-72c0-3c30-93a264e96f43aeaf.pdf.

[25] [Page, A. L, 1982. Methods of soil analysis. Part 2. Chemical and microbiological properties. Madison. https://www.cabdirect.org/cabdirect/abstract/19841981415.

[26] Pannu, B. S., Dang, Y. P, Verma, K. S, and Verma,. S. S, 1985. Effect of phosphorus on the yield and quality of sugarcane. India Sugar. 35: 263-265.
[27] Sahlemedhin Sertsu., 1999. Draft guidelines for regional soil testing laboratories. NFIA, Addis Ababa, Ethiopia. 10.4172/2329-8863.1000411.

[28] Sarwar, M. A., Husain, F, Ghaffar, A, and, Nadeem, M. A. 2011. Effect of some newly introduced fertilizers in sugarcane. Pakistan Sugar Kournal. 26: (.01): 2-7.

[29] SAS. 2004. Statistical Analysis Software version 9.0, SAS Institute Inc. Cary, NC, USA.

[30] Shrivastava, A. K, 2006. Sugarcane at glance. International Book Distributing Co. (IBDC) Lucknow, U. P. India. https://www.sapnaonline.com/books/sugarcane-glance-ksrivastava-8181890981-9788181890986.

[31] Singh, A. K, Shukla, M.S. Gilt,. Sharma, S. K and Tiwari,. K. N. 2008. Improving sugarcane productivity through Balanced nutrients with potassium, sulfur, and magnesium. Better crops India, Uttar Pradesh, pp. 1-14. HTTP://www.ipni.net/publication/BCA.nsf/0/06ABF64813A3 67B3852579A4007A9E5D/\$FILE/Sugarcane\%2008095\%20B C\%20India.pdf.

[32] Singh,. R. K, Pandey, R. N, Singh, S. P, Rastogi,. J and Sharma,. M. L, 2014. Early assessment Of Genetic fidelity in sugarcane (Saccharum officinarum) plantlets regenerated through direct organogenesis with RAPD and SSR markers. Australian Journal of Crop Science, 6 (4): 618-624. http://www.cropj.com/singh_6_4_2012_618_624.pdf.

[33] Sugar Corporation, 2018. Annual Report of Finchaa Sugar Factory in Finchaa, Ethiopia. https://www.dnb.com/businessdirectory/company-

profiles.ethiopian_sugar_corporation.4d3bd344ca983a31ac1b 42d8a575b729.html.

[34] Sugar Corporation,. 2017. Annual Report of Ethiopian Sugar Corporation in Addis Abeba, Ethiopia. https://www.dnb.com/business-directory/companyprofiles.ethiopian_sugar_corporation.4d3bd344ca983a31ac1b 42d8a575b729.html.

[35] Swapna, M. and Srivastava, S. 2012. Molecular Marker Applications for Improving Sugar Content in Sugarcane, Springer Briefs in Plant Science, DOI: 10.1007/978-1-46142257 0_1. https://link.springer.com/book/10.1007\%2F978-14614-2257-0.

[36] Tisedale, R, 009. The effect of different rates of Nitrogen and Phosphorus fertilizer on sugarcane yield. International Book Distributing Co. Lucknow, India.

[37] Toomsan, B and Limpinuntana, V, 2005. Effect of phosphorus on physiological and agronomic parameters of sugarcane cultivars in Thailand. Pro. Int. Soil. Sci. Technol. 25: $126-$ 131 https://staff.futminna.edu.ng/SLM/content/journal/PF0906/32. pdf.

[38] Worku Burayu, 2005. Agroecological conditions and background information on Finchaa Sugar Factory, Finchaa Research Station, Ethiopia. 